\title{
RURAL MIGRATION PROCESSES IN MEXICAN COUNTRYSIDE
}

\author{
José G. Vargas-Hernández \\ University of Guadalajara, México
}

The purpose of this paper is to analyze the empirical-theoretical approaches to shrinking cities in Mexico. The study of tendencies in economic and environmental shrinkage is tied to the expressions of substantive changes in the complexity of determinant contexts of internal and migration flows. The analysis intents to answer the challenges posed by current economic and demographic tendencies, using theories and models and trying not to fall down victim of simplistic projections and conjectures and theories based more in speculations rather than on facts. The method used is the critical analysis of economic, social and political tendencies around the phenomenon of shrinking cities in México. The results of this analysis lead us to the conclusion that the shrinkage process in México, as a developing and emerging economy does not follow the same patterns as in well developed countries, where an increase in shrinking cities has been observed since the middle of the 1950s and the use of incentives in some localities to attract economic growth have had rather modest success in turning around the shrinking process. Further research on shrinking cities should be done in México. Finally, this paper analyzes some of the problems which are important for setting the agenda for future research in Mexico.

Keywords: economic decline, shrinking cities, theories of shrinking, Mexico.

\section{Introduction}

Research on shrinking cities is a relatively new field for Mexico. Studies on this topic are often criticized for lacking theoretical foundations or for insufficient reference to theory while explaining the empirical findings. This paper is aimed, inter alia, to address this criticism.

The issue of shrinking and decline in population and economic prowess always provokes quick, large-scale and often emotional reactions due to political sensitivity of all the related issues. In general terms, shrinkage is only one side of the coin, while growth is the other one. Mexican researchers and academicians are more concerned with the fast growth of population rates with all its spatial and territorial implications. While more advanced and

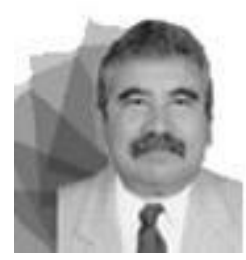

\section{José G. Vargas-Hernández}

$\mathrm{PhD}$ (Public Administration) degree from Columbia University and $\mathrm{PhD}$ (Organizational Economics) from Keele University.

$\mathrm{He}$ is a member of the National System of Researchers of Mexico and a research professor at the University Center for Economic and Managerial Sciences, University of Guadalajara, Mexico.

Areas of his scientific interests include organizational economics, strategic management and global marketing. The author has participated in more than 200 international academic events and in more than 500 national events; published 4 books and more than 200 papers in international journals (some translated into English, French, German, Portuguese, Farsi, Chinese etc.) and more than 300 essays in national journals. 
postindustrial economies of the world are thinking how to turn around the cities' shrinkage into steady growth, less developed economies worry predominantly about the too fast growth rate of urban population along with its territorial redistribution.

It seems to be necessary to develop a shrinkage typology to better characterize this phenomena. One point is especially important to be underlined here. While advanced countries are talking about the shrinkage process as the result of postindustrial/postmodern development, in México the industrialization process is still at its initial stage, and this process is taking place due to rather atypical causes, such as the most urgent drive of people for survival.

In general terms, the situation with shrinking cities in México does not follow the same patterns as those of well developed countries, where an increase in shrinking cities has been observed since the middle of the 1950s (Oswalt, 2005) and the use of incentives in some localities to attract economic growth have had modest success in turning around the shrinking process.

There is a variation of conceptual and theoretical proposals applied to analyze the decline and shrinking of human settlements. Flows, decisions, phases, stages and composition of migration (Tuirán et al., 2000:31; Brown, 1991) are often included in the evolutionist schemas and theories about the phases of economic development or social modernization. Of course, these evolutionary schemes do not have general applicability because in some cases they are related only to determined movements such as exchanges between regions, urban and rural zones, between the center and the periphery in metropolitan areas etc.

Studying the tendencies in economic and environmental shrinkage is often connected to the expressions of substantive changes in the complexity of determinant contexts of internal and migration flows. Population mobility is the strategic rational response of survival in an unstable economic, social and political environment. At the same time, it is important to analyze the tendencies around economic changes using the theories and models and no to fall down victim of simplistic projections and conjectures or resound theories based mostly on speculations rather than facts.

Overall, the determinant factors of shrinkage are suffering mutations as the result of the new economics and the emergence of new forms of population mobility. The background for these changes in Mexico is formed by economic liberalization and structural adjustment programs, increasing capital mobility, newer demands from the labor market, advances in telecommunications and transportation means, productivity conversion, increase in exporting activities, relocation of industrial activities etc.

Originally, gravitation approaches were dominating in explanations of migration flows and their dependencies, however, gradually the list of the factors to be considered in this regard has been seriously widened and started to include various economic, social, environmental and political factors.

\section{Spatial distribution of Mexican population}

The actual spatial distribution of population in Mexico is marked by the path dependence based on circular and accumulative causation oriented onto large investments and gradually increasing operating returns as well as scale economies. Some areas of high population density go back to the Aztec period, actually. 


\section{RURAL MIGRATION PROCESSES}

At the international level, Mexico is the 11th most populated nation on this planet, the second one in Latin America and the 14th in terms of territorial extension. Mexican population is rather unequally distributed all over the territory of the country.

In 1950, the population density was 13.1 inhabitants per square kilometer and in 1995 it was already 46 inhabitants per square kilometer. By population density Mexico is \#8 in the world, with 46.7 inhabitants per square kilometer. Thus, México is also among top-10 countries with the highest population density (Banco Mundial, 1994).

In order to determine whether city's population is growing or shrinking, we should first calculate the data on the natural growth rate of population, then adding or subtracting the net migration rate. Some studies suggest that population redistribution stems, in the first place, from the existence of positive or negative migration, while territorial differences are of secondary importance.

In the last 50 years in México the process of spatial redistribution has been very much noteworthy, urbanization has reached the level of almost $80 \%$ while serious demographic stagnation has been observed in rural areas, being an obvious consequence of population expulsion. Among many explicit tendencies of the recent 50 years, we need to mention, inter alia, occupation of the traditionally empty spaces on the Yucatan Peninsula and the adjacent areas to the Rio Bravo and Rio Grande on the USA-Mexico border. When many enterprises of the Northern Mexico closed because their owners decided to move their businesses to China in search of lower costs and higher profits, the local large cities (Tijuana, Mexicali, Cd. Juárez, Nuevo Laredo, Reynosa, Matamoros) and the territories more or less nearby the border still continued to receive migrants from the South of Mexico and other countries of Central America too.

Af of today, population is mostly concentrated in the states neighboring Mexico City, that is, the states that are most important for economic and industrial development: Estado de México, Distrito Federal, Veracruz, Jalisco y Puebla - these states account for only $10.7 \%$ the national territory but at the same time they also account for $41.2 \%$ of the national population.

\section{Rural Migration}

The agrarian reform initiated back in the 1930s has resulted in intensification of rural migration to large cities, including Mexico City (Tomas 1997: 233-234). Mobility of population in the direction from rural to urban areas has had its strong impact on the territorial expansion of large cities, while reconfigured demographic relations, in their turn, have forced further changes in economic policies.

Soon larger cities receiving rural migration inflows became congested, so the newer solution to the problem was rural migration from Mexico to the United States, partially regulated by the Bracero Program and partially illegal (Reyes Morales, 1999; Duhau \& Schteingart, 1997). Ladent (1982) estimated that in the case of Mexico the peak of rural migration to urban centers falls on the seventies and eighties.

At the same time, Mexican population has been experiencing sustainably high fertility rate, gradual decrease in the mortality rate and more of spatial redistribution. These factors taken together have also contributed to the accelerated growth of migration and thus - also to further urbanization of the country. This process of accelerated urbanization exceeded the limits of planning and presented many challenges to development despite sustained economic growth. 
In Mexico migration is mostly carried out by young individuals and in a greater proportion by women (Cabrera, 1970). As the overall data on international migration shows, illegal migration is always greater in volume than the official one (Cornelius, 1978). Since more and more women are migrating from villages to cities, rural areas are also experiencing declines in fertility rates since less young women stay in their native villages to have families and raise children there.

Migration flows of Mexican rural population is oriented on metropolitan areas mostly and also on crossing the international border with the United States.

Greater dynamism of Mexican urban areas always attracts rural population that is looking out for better means for its reproduction, although urban life does not necessarily offer all the facilities and opportunities for all immigrants from rural territories. Mexico has been experiencing really rapid growth of urban population with an obvious trend of economic, political and demographic concentration in large metropolitan areas such as Mexico City, Guadalajara, Monterrey, Puebla, Leon, Tijuana etc., which are consolidated under the new economic model supported by economic neoliberal reforms.

Accelerated and expansive growth of urban and metropolitan areas on the North and Center of the country has reconfigured the migratory flows from the rural zones. Migrants are heading to agglomerations so that to "insert themselves" into their labor markets but that requires certain labor qualifications (Chávez, 1999, Chávez and Galindo, 2006, Pérez, 2007).

Displacement of rural population in Mexico in the direction of cities on the North (and partially also in the direction of the United States of America) is the result of growing inequalities in socioeconomic development and the lack of labor opportunities. Border metropolitan areas tend to receive the greatest inflows of migrants but with extremely low levels of education. However, the labor market demand in the destination points actually requires these low labor qualifications because sectors with low productivity still dominate at these labor markets.

Since the eighties of the last century, Mexico has been implementing structural reforms, to the extent that it has modified the entire economic system to have much stronger impact on rural population. Increasing rural migration throughout the $1980 \mathrm{~s}$ has been associated with the economic policies being focused on structural reforms discouraging small rural production and thus forcing peasants get more actively engaged into wage labor and thus use their remittances to improve their standards of living.

The economic policies of structural adjustment initiated in Mexico back in the eighties have transformed the whole of rural economy, forcing the peasants to seek complementary alternatives so that to obtain extra economic resources and satisfy the growing needs of their families. The fact is that today the number of salaried persons in a typical Mexican household is equal to the number of migrant members, and this can be treated as probably one of the most negative implications from structural adjustment policies implemented in relation to Mexican rural areas.

Structural reforms introduced in Mexico since the 1980s along with technologies used in the Mexican countryside have produced labor surpluses, thus causing significant displacements of day laborers, mainly migrating to seek alternative job opportunities in other economic sectors so that to improve their wage level. The assumption can be made that structural reforms in Mexico has had serious economic, political and demographic concentration effects. Although this tendency of concentration is not absolute, urban centers 


\section{RURAL MIGRATION PROCESSES}

experienced significant demographic growth due to migration inflow from the countryside, thus, cities have also experienced greater economic growth.

Also, due to structural reforms in Mexico, spatial occupation of population has been transformed (Chávez and Lozano, 2006). Now it is mostly concentrated in 15 metropolitan areas, each having over $1 \mathrm{mln}$ inhabitants. Rapid growth of these metropolitan areas is due to changes in migratory flows which, in their turn, are due to transformations in the national economic model (Ariza and Ramírez, 2004; Sobrino, 2010). The increase in rural migration has been mostly the result from the implementation of economic policies related to neoliberal structural adjustment that has eventually forced many peasants to look for alternative employment opportunities that by default require low qualification.

Although the overall trend of population mobility between metropolitan areas stabilized in the 1990s already (Ariza and Ramírez, 2004; Pérez and Santos, 2008; Sobrino, 2010), the flow of migrants from Mexican countryside to larger cities still continued to increase for some time. The growth of migration has been reducing very slowly and then has achieved a certain stabilization point. Rural migration to urban centers at some point has decreased while urban migration to other urban centers and larger metropolitan areas has again increased (Cabrera, 1967; Sobrino, 2010).

In the recent two decades, migration movement from rural areas of Mexico to large urban centers has decreased as compared to the migration flows between urban and metropolitan areas (Perez Campuzano and Santos Cerquera, 2013). Slowing down was especially noticeable if compared to the rates observed during the 1960-1970s. This deceleration of internal migration could be partially explained by the dramatic effects of the 1980 s crisis and further quite slow economic growth throughout the nineties.

According to the data from the population census as of 2000 , migration of population from rural areas to metropolitan areas was on the level of $6.7 \%$ and between various urban areas it was about $3.9 \%$, thus, the total was at the level of $10.7 \%$. In 2000, the rural-urban flow was about $21 \%$, while urban-urban flow was $64 \%$, urban-rural flow was $11 \%$ and finally the rural-rural flow was $4 \%$. Therefore, serious changes are observed in the main directions of migration, mainly, rural-urban, urban-urban and urban-rural. The current flows are observed mostly from rural areas and smaller cities to mid-sized and large cities (Sobrino, 2014).

Rural-urban migration actually predominates in the absolute majority of developing societies, and in the course of their advance, the flow of migration decreases in both absolute and relative terms. In the case of Mexico, the decrease in rural-urban migration was first observed after 2000, and today contribution of migration to urbanization is less than the natural growth. In the first decade of the 2000s, rural population of Mexico, in absolute terms, became significantly smaller, thus, the flows of rural migration became much smaller as well. However, we should keep in mind the reclassification of urban and rural localities in Mexico which has causes serious statistical changes in interpretation of migration.

The 2000 General Population and Housing Census (INEGI) reported that $4.35 \%$ of all households received remittances, with higher percentages belonging to the households in rural municipalities that obviously have migrants working in Mexico's urban centers or somewhere abroad. Therefore, access to the markets for rural households largely depends on the remittances received from migrants originally from rural households who do not have income from any activities, including agricultural ones. 
The Population Census of 2010 presented migration of population from rural areas to metropolitan areas to be at the level of $10.7 \%$ and to urban areas - at the level of $5.3 \%$, thus yielding the total of $16 \%$. In 2010 the rural-urban migration flow decreased to $6 \%$ while the rural-rural flow remained at almost the same level - 4\%. Interestingly, urban-urban flow increased to $67 \%$ and the urban-rural flow also increased - up to $13 \%$ (Sobrino, 2014).

The migratory flow from rural areas to the metropolitan zone of Mexico City is the most obvious one, of course. Back in 1970, migration was predominantly rural-urban. The states where rural population was predominating generated up to $55 \%$ of the total migrating flow during the 1970s, but this number was later gradually decreasing reaching $43 \%$ as of 2010. Due to all these trends, the population growth rate during 2000-2010 in rural communities and small cities turned out to be below the national average.

Another trend applicable to México is that mobility from urban centers to rural areas has been gradually increasing (Jones, 1990) following the movement known as deconcentration of population (Champion, 1989, 2001; Long and Nuccy, 1997; Elliot, 1997; Boyle and Halfacree, 1998; Boyle et al., 1998; Johnson et al., 2005). As a result of large migration flows of population living in rural areas dwarfs numerically in both absolute and relative terms, giving space to changes in the trends of population mobility in the points that were previously attractors and now became extractors. The main urban destinations for rural migration have been also transformed into the main centers, now expelling population in inter-urban migration or from urban centers to rural areas.

In Mexico, according to the data of the National Institute of Statistics and Geography and taking into account the political-administrative territorial delimitations, in 2007 the Social Development Secretariat (SEDESOL) and the National Population Council (CONAPO) determined 56 metropolitan areas, urban municipalities - those that have at least one town with more than 15 thousand inhabitants, and rural municipalities - those with all their towns being under 2500 inhabitants each.

Back in 1900 only $6 \%$ of the total population were migrants, in hundred year from then, that is in 2000 , already $18 \%$ of the total population were registered as migrants. The population concentration in a small number of cities and at the same time population dispersion in a large number of localities with less than 2500 inhabitants are two predominant phenomena of population distribution in Mexico. The Population census of 2000 identified 196 thousand localities with less than 2500 inhabitants with the total population of 24.6 million inhabitants. These localities of less than 2500 inhabitants are characterized by various levels of geographical, economic, political and social marginalization.

However, the percentage of people living in rural communities has also decreased. In 1950, such smaller localities represented over $57 \%$ of the total population; in 1990 it was $29 \%$ and until 2010 this figure decreased to the level of $22 \%$ only. In 1950 , about $43 \%$ of the overall Mexican population lived in urban areas, in 1990 - already 71\%, and as of 2010, this figure increased to almost 78\%. From 2010 to 2015, migrants who returned (because they were forced to do so or voluntary) from the United States to rural locations represented $29 \%$ of the total population in Mexico. In 2016, it was estimated that about 12 million Mexican migrants were residing in the United States of America, at least according to the report prepared by BBVA Bancomer, the National Population Council (CONAPO, 2017).

With low rates of economic growth, urban centers lose their economic and demographic attractiveness for rural migration. Migrants from rural areas today are more attracted by the opportunities offered by mid-sized cities (Geyer, 1996) while larger cities are 


\section{RURAL MIGRATION PROCESSES}

characterized by the so-called differential urbanization (Geyer and Kontuly, 1993) and the transition of mobility (Zelinsky, 1971). Territories that experience a decrease in their economic activities are also those that begin to experience a demographic decrease, and quite soon, due to the urgent need of population to seek for better sources/resources to improve their living conditions. In other words, the relationship between socioeconomic development of a region and migration to/from it is always two-way.

Demographic consolidation of urban centers and the geographic distribution of the population has been the result of changes in the composition of migration that is manifested in a decrease in rural migration and an increase in intra-metropolitan migration. Rural population has decreased its outflow to large cities while migration from mid-sized cities to rural communities gradually became quite relevant.

Rural migration will continue to exist as long as the current conditions would not change significantly, and also as long as neoliberal economic policies would continue to dominate. Neoliberal structural adjustment policies in Mexico are aimed mostly at the agricultural sector and more specifically - at prevention of outbreaks and other social tension among rural population.

\section{Historical Approaches and Resource-Based Theory}

There is vast amount of literature dedicated to the analysis of case studies on the rises and falls of mining cities and towns in Mexico, all being under strong and direct dependence on mining firms. Most of these studies though have historical and sociological theoretical framework.

Most of these case studies also contain some sort of historic interpretations of the related events, including those directly related to economic history. Their limitations and misinterpretations often depend on the depth of the analyses done by the historians regarding the history of mining in Mexico and the country's colonial history in general. The key methods applied in these historic explorations are revision and compilation of the studies related to the topic of shrinking cities. Interpretations are often carried out under the optics of historic materialism, procuring to show the contradictions that characterized the mining activities as part of the colonial exploitation scheme. Referring to the theory of the second contradiction of capitalism, O'Connor (2001) sustains that economic growth since the industrial revolution has been achieved at expense of high costs for the autonomy of human communities worldwide.

Historic materialism and the already mentioned Marxist revisionism together have set the theoretical framework for further focus the problem. This approach does not necessarily means radicalization of the related views and actually leaves enough open space to scientific reasoning under different theoretical perspectives that can provide support to the analysis of the problem under study.

The method of historic interpretation used here is sociological in nature. It begins with understanding of the inherent logic of the studied phenomenology in general, in a rather deductive manner, and later is proved using inferential statistics on the particularities of the related phenomenon. All interactions are treated at the macrosocial level, while research hypotheses are formulated at the microlevel.

The resource-based theory may offer a framework for further research of these historical and sociological recounts concerning the phenomenon of shrinking cities. 
Generally speaking, resource-based theory provides the framework to explain how organizations achieve sustainable competitive advantages. A resource here is understood as a kind of production factor which is at firms' disposal, that is, controlled by the firm, even if the latter does not have direct property right on it. Moreover, any resource is able to create a competitive advantage if it has certain features. Resource-based theory treats enterprises as potential creators of value-added capabilities.

This theory focuses on the idea of costly-to-copy attributes as the sources of business returns and the means to achieve superior performance and competitive advantage (Barney, 1986; Conner, 1991; Hamel and Prahalad, 1996). As Grover Grover, Teng, and Cheon (1998:84) explain, "the essence of the resource-based theory is that given resource heterogeneity and resource immobility and satisfaction of the requirement of value, rareness, imperfect inimitability, and non-substitutability, firms' resources can be a source of sustained competitive advantage". One of the objectives under this theory is to appreciate competences as firms' most valuable assets and, at the same time, to understand how these assets can be used to improve business performance.

The historic roots of urban settlements in Mexico can be found in the logic of the conquerors that urban localization can be easily used for the achievement of economic, political and ideological objectives. During the colonial period in México, mining was the gravitational sector of socioeconomic development as such, it was the primary sector and also the key export scheme under the metropolitan-periphery colonial dependency. At the same time, capitalism has been gradually shifting from bilateral mercantilism to multilateral industrialism. Local economies of different Mexican regions remain to be very much obedient to transnational interests during different stages of their historic development: colonialism, economic liberalism, industrialization through import substitution and finally the current neoliberal regime.

Colonization of New Spain was also characterized by dramatic demographic reduction among indigenous population. By 1518, the year before the arrival of Cortés to the Mexican land, the indigenous population was estimated to be between 16 and 25 million people (Borah, 1982; Cook and Borah, 1980; Cook and Simpson, 1948). One century later the indigenous population was already slightly more than 1 million, and this was the catastrophic result of not only wars and conquest but also of several epidemic illnesses.

The Spaniards were interested in metals, not people. And this factor became the main reason for population mobility oriented on exploration of new territories in order to find more silver and gold and organize mines there. The Iberian migrants were also driven by the belief that their wealth was given by the God through precious metals which in this case it somehow not treated as the product of work. The discovery of silver deposits in Zacatecas in 1546 became the first colonial antecedent to start the population mobilization to form new settlements near the mines. Other natural deposits of gold and silver were discovered in Chihuahua and later also in San Luis Potosi. The Northern region of Mexico quickly became quite densely populated, and quite heavy (for those times) transit and traffic were observed between these localities and the México City.

Such internal economic structure was oriented predominantly on exploitation of natural resources. The flow of transnational capital was much more important than the welfare of Mexican population and its demographic development. Numerous cities, towns and villages were founded under this logic. When the economic gravitational forced shifted to other countries and regions, following the interests of international economic structures, all these 


\section{RURAL MIGRATION PROCESSES}

Mexican cities and towns quickly declined and shrunk, thus showing that colonial heritage is not development but rather underdevelopment. Today, most of these once affluent and wealthy cities are ghost towns or have already disappeared from the map as such.

Vargas-Hernández (2007) analyzed the shrinkage of mining towns in Mexico, some of which are still going through these shrinking and declining processes after having their enormous impact on economic development of Mexico. This shrinking process observed in the absolute majority of mining towns posits a trap and a dilemma for economic development of the whole country: on the one hand, these are obviously ghost towns already; on the other, their inhabitants are often mobilizing to defend their historical and cultural heritage. Also, environmental problems and just the issues of survival force these mining companies along with local population to find alternative activities such as tourism which potentially may bring in the so needed resources to these territories.

\section{Evidence on The Mining Towns' Shrinkage in México}

Mining has been having a tremendous importance for Mexico's economy. The state of the mining industry was the key economic indicator during the colonial times in Mexico. And even during the pre-Hispanic times, mining already played an important role in political and economic history of these territories. Spanish colonizers were attracted by the already opened rich mines and with the discovery of new ones they got attracted even more. Mining activity was the key incentive for foundation of new villages and towns far away from large cities and even under the conditions of difficult access. Houses were built with adobes covered with tejamanil on the slops of the mountains, under the conditions of nearly permanent dense fog, without any order or sense of space, strictly according to the needs of the mines not the people (Flores Clair, 1997). These new villages and towns were populated and quickly grew to reach the status of cities during the colonial times already.

The very first mine was established in the Nueva España in 1532, later very much giddy exploitation of precious metals followed all over the territory. Location of gold and silver as the key mineral resources to be exploited predetermined the whole process of ongoing colonization. The factor of precious metals oriented Spanish conquerors in their population mobility on the exploration of new territories and settling new towns and villages mainly in the highlands (Zacatecas, Chihuahua, San Luis Potosí etc.) and lowlands (El Bajío, Guanajuato, etc.) around the gold and silver mines.

In 1564 and further opening of the mines in Guanajuato initiated truly massive migration so that to populate Guanajuato and the Bajío. The whole regional production system of Guanajuato was linked to the mining production and to provision of necessary goods and services to Zacatecas and further to the North. The scattered haciendas (ranchos), villages and towns founded in the El Bajío were the economic units producing goods and services to be supplied further on these territories. Mining activities had their sustainable growth even before 1600, all related towns and villages also grew, many of them got the status of cities, such as Zacatecas and Guanajuato.

During the 16th century, all locally populated areas were concentrated around these mining centers, congregations and haciendas. Their agricultural production was aimed at local self-consumption, while all mining activities were aimed at exporting gold and silver to Spain, however, not with commercial purposes but to accumulate and treasure. 
Thus, Mexican mining sector was the gravitational center of the colonial production system. Villages, towns and cities founded in the course of this sector development followed this logic, therefore, they also began to shrink when the mines radically decreased their activities or stopped production as such.

The local demographic catastrophe of the 16th-17th centuries caused drastic scarcity of manpower and the shrinking of mining cities and towns. The Crown directly and indirectly limited the participation of indigenous population in such activities as mining, agriculture, various industrial jobs. This inevitably lead to the situation in which many goods and services became too expensive, thus spoliation took place more and more often. Roughly the same time the indigenous population was gradually substituted by the Afro-Caribbean people who were introduced to México. The mining sector demonstrated sustainable demographic growth until the beginning of the 1620s-1630s when the crisis started due to the insufficient supply of mercury necessary for further exploitation of silver mines. Mining cities, towns and villages immediately began to shrink.

There were no regulations over the civil population residing in the mining-dependant cities and towns. At the middle of the 16th century, exploitation of the still prolific seams became the main cause of various emergences taking place all over the mining towns on the territory of New Spain.

Most of these small mining towns later became the cities of great economic and social importance, among them - Pachuca, Hidalgo, Parral etc. Exploitation of precious metals achieved truly outstanding growth by the end of the 16th century, it represented more than $80 \%$ of the total exports outflowing from the Nueva España (Estrada, 2001). Mining was still the motor of the whole regional economy, all other economic activities emerged somehow around it. Together they provided employment, allowed commercial trade with the metropolis and overall gave rise to prosperity in the mining towns and cities.

There are many issues regarding the economic history of México still requiring explanation. One of these issues is the debate on the decline of Mexican economy during the 17th-18th centuries. One of the key reasons behind this decline was mining production itself, according to some of the opinions. On the other hand, there is no economic evidence to prove the hypothesis that mining in Mexico was experiencing a profound crisis during the 17th century (Ibarra, 1995). Moreover, production of silver multiplied twofold through the 18th century.

Explaining the meaning of the colonial mining activity, Galeano once said: "In Potosí the silver built temples and palaces, monasteries and gambling dens, offered motive to tragedy and the feast, spilled over blood and wine, inflamed greed and untied squandering and adventure" (Ibarra, 1995). Later on, with the decline in mining, life in mining cities became harsh and troubled, with all types of contrasts, ambitions, and disorders manifested within this harshness.

Decline of the mining industry started in 1810 although its official cause is rather questionable: the movement for Mexican independence and the lack of stable political and social institutions. With the independence of Mexico gained in 1821, the whole system of colonial production with its central role attributed to mining lost its leading economic role. Mining cities, towns and villages quickly shrunk. The mining sector lost its potential to lead the industrial revolution in México.

However, during the second half of the 19th century, decline in the mining activities brought about the shrinking process into the mining cities up to the level of converting many 


\section{RURAL MIGRATION PROCESSES}

of them into ghost towns. It was until the era of Porfirio Diaz (1880-1910) that the mining activities had a modest growth, mostly due to exploitation by English and American mining companies that were often insufficient to provide enough work for the expansive growth of already quite populated areas. Recent changes in Mexican legislation have liberalized the mining sector and after signing the North America Free Trade Agreement (NAFTA) foreign companies have increased investments in these areas.

In Mexico, some early mining towns faded into obscurity while others became the centers of ranching and commerce, still even those were quickly abandoned after the decline of mining activities.

Mining towns, with their fabulous baroque architecture, were located mostly in mountain areas. They did not follow the geometric layout but were quite well adapted to the topographic condition of the localities. The conquest of Northwest Mexico lead to the establishment of colonial towns located on the Sierra Madre Occidental where mining was the main economic activity. The State of Sonora also in the Northwest of Mexico has been same wealthy in terms of mineral resources. This locality was the first producer of gold and later also of silver, copper, and other metals. Once the NAFTA was signed, more than 70 foreign mining companies have established offices in Hermosillo, the capital of the State. However, exploitation of local mines situated around Guadalupe de los Reyes, San José de las Bocas and Cosalá started much earlier, back in the 16th century already. Cosalá was founded in 1562 and in the 19th century it became the most important area in this region, in 1898 it produced $50 \%$ of all silver exported by the State of Sinaloa.

Among the outstanding mining towns on the North of Mexico we also need to mention La Bufa, Batopilas, Cerro Colorado, the Raramuri communities of Munérachi, La Yerbabuena, and the Jesuit mission of Satevó with such important mining centers as Urique, Maguarichi, Uruachi and Ocampo, Batopilas. Batopilas has preserved, to a great extent, its architectural heritage and till now demonstrates the richness of those times. At the peak of the mining period (the end of the 19th century) Batopilas used to have up to 7,000 inhabitants. Today, the local community of 800 inhabitants only.

The mining towns Concepción del Oro y Mazapil were far away from Real de Minas Zacatecas. In 1569, Mazapil had around 150 Spanish settlers. Both mining towns achieved greater economic status during the XVIIth-XVIIIth centuries. However, today both these cities are not even on the maps of México. In the Northeast of México, the first settlements such as San Gregorio (1577) and La Trinidad (1577) were based in the immediate proximity to silver mines. The mines of La Iguana near Lampazos were discovered much later, in 1757 already.

Mineral de Pozos (a rough translation might be Mineral Wells) is an old mining town in the State of Guanajuato. It was founded in 1576, and initially it was built as a fort, to protect the silver route from Zacatecas to México City. During the 19th century, the town experienced lengthy periods of nearly complete abandonment due to armed movements in the area. However, Mineral de Pozos still managed to become one of the richest of the colonial mining towns, reaching the peak in its development in about 1890 . However, the revolution of the early 20th century pushed the town into complete poverty.

Now, Pozos is gradually reawakening from being a small village trapped in the abandonment straight after being a relatively large and prosperous city during the period of mining exploitation. You can still see once neatly paved streets but also semidestroyed large colonial adobe homes and dismantled buildings that used to be sumptuous. On 1982 the town 
was declared to be the Historic Monument of the Nation. From the population of more than 70,000, it shrank to less than 4,000 (as of 1982). Today, about 8 thousand people reside here, most of them live below the poverty line.

At the turn of the 20th century, the population started to grow, quickly reaching the level of 80, 000 of mainly immigrants from abroad and from the neighboring states who were attracted by the potential opportunities to get wealthy. Important infrastructure objects appeared here also quite quickly, including schools, commercial centers, hotels, restaurants etc. However, in the early 1950 s already the town had only 1,000 inhabitants, thus becoming a truly ghost town in its complete abandonment. Today around 5,000 people are living there.

San Sebastian in the State of Jalisco is one of the oldest mining towns in Mexico. It was founded in 1605 and reached the highest rate of growth and prosperity during the 17th and 18th centuries when more than 20,000 inhabitants populated the town. The population numbers fluctuated following the fluctuations in the production volumes of gold which was a popular economic activity in the area until 1930. Nowadays, it has only 600 inhabitants retaining the colonial heritage such as public buildings and houses. Today the town of San Sebastian is an extraordinary example of the traditional living forms of labor in a remote village.

Real de Arriba in the State of Mexico is another enchanting mining town with a splendorous past. Today, its remaining walls are mostly ruins in the forest reminding us of the great colonial miners' homes and infrastructure buildings which once witnessed a real economic boom in the area. The city of el Oro de Hidalgo, also in the State of Mexico, used to be considered the second richest just after Transvaal, in Africa and it still has wealthy architecture thanks to its mining history. The local museum shows minerals from the mines La Esperanza, Chihuahua, Tiro México, Tiro Skip, La Calera, La Providencia, San Patricio, El Nolan, El Consuelo, La Victoria, Santo Domingo y La Aurora.

The mining district of Pachuca-Real del Monte and El Chico studied by Navarrete (2004) has its most prosperous period in the second half of the 18th century. Real del Monte got its name in 1577 already. An anonymous source mentions there were 1, 300 inhabitants here at the end of the 16th century. In 1610, there were already 1,683 inhabitants. At the end of the 17th century the traveler Giovanni Francesco Gemelli Carreri mentioned 12,000 inhabitants in his records. Using the parish church data as of 1768, which only registered population in the communion, he estimated that Real Del Monte achieved its largest population around the middle of the 18th century. After that, the population started to decrease gradually until it reached its lowest level at the end of the first decade of the 19th century. Real del Monte then produced $10 \%$ of the silver of the Nueva Spain (Hausberger, 1995) and had the population of 7,152 inhabitants.

The military census of 1791 reported that the Jurisdiction of Pachuca had the population of 9615 inhabitants out of which the 26.7\% (or 2567 persons) forming 608 families belonged to Real del Monte, although the census did not consider indigenous people, women and children under 16 years old. After 1824, Real del Monte changed its name to Mineral del Monte. In 1858 the population of Mineral del Monte was around 6000 inhabitants, while the Census of 1854 registered 5310. In 1865 the census of men older than 18 years registered 1005 hombres and/or 700 families. Comparing the data of the censuses as of 1791 and as of 1865, the number of inhabitants was almost similar. This leads us to the conclusion that for around 7 decades the growth of population was literary at the zero level. 


\section{RURAL MIGRATION PROCESSES}

Very good examples of similar trends are Charcas, Real de Catorce, Guadalcazar y Cerro de San Pedro in San Luis Potosi, also ghost towns that once used to be important mining cities. Nowhere in Mexico are the changing styles and fortunes of former gold and silver mining towns are better manifested as in these four towns.

Let's take Charcas, for example. This town was founded in 1584 and used to produce over 3 million dollars' worth of silver each year. Today only a few old large stone houses survived there. Real de Catorce also had a grandeur past with gorgeous buildings, outstanding church and a beautiful Palenque. In Guadalcazar, the miners built two magnificent churches and a Casa de Moneda. San Pedro, founded in 1592, was fully abandoned about fifty years ago.

\section{Analysis of the case studies on resource-based firms related to shrinking cities}

There are some case studies that analyze the relationships between resource-based firms and the process of cities' shrinking. These days similar cities and town are sometimes called "corporate city" and "corporate town". One of such case studies has been aimed to analyze the environmental and economic shrinkage of Atenquique after the industrial boom (Vargas-Hernandez, 2007). The town of Atenquique was founded and grew up in terms of population, social and economic development in parallel to the development of the Industrial Company of Atenquique during the period when this company was owned by the Mexican State. After the Company has been privatized, the town started declining and shrinking in population, social and economic development, but the most disastrous aspect was the emergency of environmental hazards. The turning point became the conflict between the Union and the new owners of the Company. This conflict basically represented the struggle for survival of the older project of welfare state and the newer hegemonic project, stemming from the neoliberal model of development.

Negative environmental and economic impacts initiated the shrinking of not only Atenquique but also of other surrounding cities and towns, while the new owners were increasing the levels of productivity and profitability. Therefore, the focus in the analysis of such case studies should be always on the contrast between the newly emerged successful firms (wherever applicable, of course) and the shrinkage of older towns.

\section{Agenda for Future Research}

Further research on Mexican shrinking cities is obviously needed. Some of the important issues and problems to set the agenda for such future research in Mexico are:

Research could be carried out on economic territorial valuation and local real estate markets using tools of the so-called "new economic geography" (Fujita, Krugman and Venables, 2000, p. 3). This might help understanding the dynamics of economic activities in their spatial distribution and in the context of local and global forces' interaction. This research would also help to explain which cities are able to play the role of global cities. The results of our research suggest in this regard the importance of such factors as sustainable economic concentration processes and relative territorial symmetry.

Another important research direction could be determining the productive vocation of different regions and cities. A multidisciplinary approach can be applied to differentiate between "winners and losers" among various areas within the same country (Benko and Lipietz, 2000; Caravaca, 1998) Localization of production activities often rejects the ideas of geographic determinism, especially when it comes to creation of a competitive advantage. 
Caravaca (1998) identifies urban regions as nearly always the winners from globalization and innovative development, second go smaller industrial districts. Sassen (1998) identifies global cities as the winners when it comes to economic and social concentration.

It is even more important to determine the losers because the latter always have their immediate impact on the process of deindustrialization. The losers are often the areas that cannot convert their local economies so that to obtain own competitive advantage. These are mostly rural economies suffering from low productivity and scarce human capital. For these two reasons such economies are not able to insert themselves into the global economy. Territorial mapping of productive structures is always relevant for understanding the patterns of spatial redistribution of population but these two are not always oriented in the same direction, actually.

More research is also needed in analyzing the relocation processes in the context of spatial redistribution of economic activities and that of population. Understanding these processes may help achieve more sustainable productive, economic and demographic dynamics along with generation of more employment opportunities.

The increasing flows of migration between large cities is a relatively new challenge for researchers. It is also directly related to residential localization and displacement of population, urban segmentation, socioeconomic territorial segmentation, suburbanization of high income groups in rural areas etc.

Social and economic stagnation of rural areas should not be disregarded by researchers either. Obviously, the accelerated urbanization process has been the main cause of this stagnation. However, by now we have already observed numerous signals of the exhaustion and overuse of the absorption capacity of cities (Castells, 1977, p. 58). In parallel to that is emerging quite an interesting phenomenon - the so-called "local identity projects", their dynamic impact on social and economic life in rural areas should be also recognized and studied.

More research should be carried out on rural labor market and urban labor market so that to analyze the impact of employment and labor trends on spatial redistribution of population. This analysis should consider, inter alia, the effects of the so-called "social erosion": when the most qualified people move from rural settlements to large cities or to other countries, leaving behind children and/or the elderly.

Rehabilitation of inner areas in large cities is another promising direction for future research, namely, in the context of improving living conditions for population and contributing to social cohesion. Integrated preservation of such areas may have its positive impact on economic development, fostering local employment through small business development, in particular.

Colonial cities, towns and villages are spread all over Mexico. Their absolute majority is still experiencing economic and demographic decline. Thus, there is an urgent necessity to launch the programs of urban heritage preservation, urban revitalization, urban rehabilitation, urban regeneration, urban renewal. Such programs can really contribute to economic growth through new jobs' creation as they are always very much labor intensive.

Urban heritage programs stem from the idea of preserving original cultural heritage, customs, traditions and national/local identity. Urban heritage preserved in a sustainable way can become an integral part of the contemporary living environment and potentially, later on may have much more far-reaching benefits for the economy and the society. 


\section{RURAL MIGRATION PROCESSES}

Preservation of urban heritage contributes to maintaining attractive and unique cities, towns and villages, with their own distinctive identity. Such cities and towns are always more likely to attract tourism and other kinds of investments as compared to cities with less pronounced identity. People often tend to identify themselves with the place they are living in. This identification, in turn, contributes to the sense of belonging and thus may have its positive impact on the social development of cities and towns in Mexico.

\section{References:}

Alsted, J. (2001). Models of human motivation in sociology. Document presented at: la Quinta Conferencia Anual de la IACR (International Association for Critical Realism), Debating Realism(s).

Ashley, C. and S. Maxwell (eds.) (2001). Rethinking rural development, Development Policy Review, 19 (4): 395-425.

Banco Mundial (1994). Rapid urban environmental assessment lessons from cities in the developing world. Banco Mundial. Vol. I-II. Washington, 1994.

Barney, J. (1986). Strategic factor markets: Expectations, luck and business strategy, Management Science,32: 1231-1241.

Boyle, P. and Halfacree, K. (1998). Migration into rural areas, John Wiley and Sons, Inglaterra.

Boyle, P., Halfacree, K. and Robinson, V. (1998). Exploring contemporary migration, Longman, Inglaterra.

Brown, L. (1991), Place, migration and development in the Third World, Londres, Routledge.

Castells, M. (1977). The urban question. Cambridge, MIT Press.

Champion, T. (1989). Counterurbanization. The changing pace and the nature of population deconcentration, Routledge, New York.

Champion, T. (2001). A changing demographic regime and evolving polycentric urban regions: consequences for the size, composition and distribution of city populations, Urban Studies, 38,4 .

Conner, K. (1991). A historical comparison of resource-based theory and five schools of thought within industrial organization economics: Do we have a new theory of the firm?, Journal of Management, 17(1): 121-154.

Davis, B., G. Stecklov and P. Winters (2002). Domestic and international migration from rural Mexico: Disaggregating the effects of network structure and composition, Population Studies, 56: 291-309.

Fujita, M., P. Krugman and A. Venables (2000), The spatial economy: cities, regions, and international trade, Cambridge, MA, MIT Press.

Geyer, H. (1996). Expanding the Theoretical Foundation of the Concept of Differential Urbanisation, Tijdschrift voor Economische en Sociale Geografie, 87 (1): 44-59.

Geyer, H. y T. Kontuly (1993). A Theoretical Foundation for the Concept of Differential Urbanisation, International Regional Science Review, 17 (2): 157-177.

Gilbert, A. (1996). The Mega-City in Latin America, Japan, United Nations University Press.

Grover, V., Teng, J. and Cheon, M. (1998). Towards a theoretically-based contingency model of information systems outsourcing, In: Strategic Sourcing of Information Systems, Willcocks, L. and Lacity, M. (Eds.), Wiley, Chichester, 79-101.

Hamel, G. and Prahalad, C. (1996). Competing for the Future, Harvard Business School Press, Paperback edition, Boston, Massachusetts.

Hatton, T. and Williamson, J. G. (2005). Global migration and the world economy: two centuries of policy and performance, MIT Press, Cambridge.

Hongchen, Y. (2008). Three essays on internal migration, Thesis for the PhD degree, University of Manitoba, Canada. 
INEGI (2010). Volume and growth of total population by size of locality for each state, 2010. México.

INEGI (2000). General Population and Housing Census. México.

Johnson, K. Nucci, A. and Long, L. (2005). Population trends and non-metropolitan America: selective deconcentration and the rural rebound, Populaiton Research Policy, 24 (5).

Jones, H. R. (1990). A population geography, Sage Publications Limited (Ltd.), Londres.

Kay, C. (1999), Rural development: from agrarian reform to neoliberalism and beyond, $304 \mathrm{p}$.

Lattes, A. and Recchini de Lattes, Z. (1996). International Migration in Latin America: Patterns, Determinants and Policies, Ginebra.

Ledent, J. (1982). Rural-urban migration, urbanization and economic development. Economic Development and Cultural Change, 30: 507-503.

Long, L. and Nucci, A. (1997). The 'clean break' revisited: Is the U.S. population again deconcentrating, Environment and Planning, 29 (8).

Mathur, Vijay K., Sheldon H. Stein and Kumar, R. (1988). A dynamic model of regional population growth and decline, Journal of Regional Science, 28 (3).

Oswalt, P. (2005). Shrinking Cities, Published by Archplus Verlag Aachen.

Perez Campuzano, E. and Santos Cerquera, C. (2013). Recent trends in internal migration in Mexico. Recent migratory tendencies in Mexico. Population papers. 19, 76.

Reyes Morales, R. G. and Gijón Cruz, A. S. (2007). Rural development, international migration and shortage of financial markets in Mexico, Trace, 52: 45-62.

Ruiz Chiapetto, C. (1999). Population and rural migrations in Mexico: Hypothesis for another century Vol. II, \#6, July-December.

Sassen, S. (1991). The global city. Princeton University Press.

Savage, M. (1988). The missing link? The relationship between spatial mobility and social mobility, British Journal of Sociology, 30 (4).

Seto, K. (2011). Exploring the dynamics of migration to mega-delta cities in Asia and Africa: Contemporary drivers and future scenarios, Global Environmental Change, 2.

Sobrino, J. (2014). Internal migration and size of locality in Mexico. Demographic and Urban Studies, 29(87): 443-479.

Vargas-Hernández, J. G. (2000). Economic and environmental shrinkage of Atenquique, Research in progress. Instituto tecnológico de Cd. Guzmán, Jalisco.

Vargas-Hernández, José G. (2006). Trapped development: the shrinkage of mining town Mexico. The Cerro de San Pedro Case. Working Paper. Instituto Tecnológico de Cd. Guzmán.

Zelinsky, W. (1971). The Hypothesis of the Mobility Transition, Geographical Review, Vol. 61, 2: 219-249.

Paper submitted

Paper accepted for publishing

Paper published online
09 April 2018

12 June 2018

30 September 2018 